\title{
The Effect of Good Corporate Governance Mechanism On The Financial Performance of Banking Companies Listed In Stock Exchange Indonesia 2012-2016
}

\author{
Desi Pipian Pujakusum ${ }^{1)}$, Sinarti ${ }^{2)}$ \\ Managerial Accounting Major, Politeknik Negeri Batam \\ E-mail: desipipian@gmail.com ${ }^{1)}$ \\ Managerial Accounting Major, Politeknik Negeri Batam \\ sinarti@polibatam.ac.id ${ }^{2)}$
}

\begin{abstract}
This study aims to examine the effect of good corporate governance mechanism on the financial performance of banking companies listed on the Indonesian Stock Exchange 2012-2016 period. The corporate governance mechanism is proxied by the size of the board of directors, the size of the board of commissioners, audit committee size, the board of director's education, and the board of commissioner's education. The company's financial performance is proxied by return on assets (ROA). Samples were taken by using purposive sampling. The total number of samples used in this study amounted to 180 research samples. This study was tested with SPSS 20 program. Data analysis technique used in this research is simple regression analysis. The results showed that the size of the board of directors, the size of the board of commissioners, and audit comitee size have a significant effect on return on assets. These three factors have a significant effect on return on assets, while the board of commissioners education and the board of director's education have no significant effect on return on assets.
\end{abstract}

Keywords: Good Corporate Governance, ROA, board member size, audit committee size, board member diversity.

\section{ABSTRAK}

Penelitian ini bertujuan untuk menguji pengaruh mekanisme good corporate governance terhadap kinerja keuangan perusahaan perbankan yang terdaftar di BEI periode 2012-2016. Mekanisme corporate governance diproksikan dengan ukuran dewan direksi, ukuran dewan komisaris, ukuran komite audit, pendidikan dewan direksi, dan pendidikan dewan komisaris. Kinerja keuangan perusahaan diproksikan dengan return on asset (ROA). Sampel diambil dengan menggunakan purposive sampling. Total jumlah sampel yang digunakan dalam penelitian ini berjumlah 180 sampel penelitian. Penelitian ini diuji dengan program SPSS 20. Teknik analisis data yang digunakan dalam penelitian ini adalah analisis regresi sederhana. Hasil penelitian menunjukan bahwa ukuran dewan direksi, ukuran dewan komisaris dan ukuran komite audit berpengaruh signifikan terhadap return on assets. Ketiga faktor tersebut memiliki pengaruh yang signifikan terhadap return on asset, sedangkan pendidikan dewan direksi dan pendidikan dewan komisaris tidak berpengaruh secara signifikan terhadap return on assets.

Kata Kunci: Good Corporate Governance, ROA, ukuran anggota dewan, ukuran komite audit, diversitas anggota dewan. 


\section{INTRODUCTION}

Banking is one business entity whose existence is well known by the public, because the business activities undertaken by the bank is closely related to the needs of everyday people, especially in terms of economy. According to Law No.10 of 1998 states that the banking business includes three activities of raising funds, channeling funds, and provide other bank services in order to raise the standard of living of many people. The activity of collecting and channeling funds is a principal activity of the bank, while providing other bank services is a supporting activity only (Kasmir, 2005).

Judging from past events regarding the banking crisis in late 1997 according to the National Committee on Corporate Governance Policy (KNKCG) is not solely because of the economic crisis but also because of the implementation of good corporate governance and the underlying ethics. One of the main causes is poor management, too risk-taking, lack of oversight of fraud and embezzlement. In addition, many more cases of banking suspects are the people within the company it self.

Quoted from news online Kompas.com Jakarta (2011), states that most of the banking cases involve insiders. In 2011 there were several cases such as BNI Branch Margonda Depok whose suspect was a vice chairman of the branch bank, the case of the burglary of the BRI Tamini Square cash office involving the cash office Supervisor and four suspects from outside the bank, the case of the BPR that made the disbursement of customer deposits without the knowledge the owner, in that case involves the president director of the BPR, two commissioners, chief commissioner, and an offender.

Some banking cases show that banks in Indonesia are still poor in terms of corporate governance. Corruption is the result of bad corporate governance. This resulted in bank losses and poor bank image in the eyes of investors and the public. If it drags on, it will cause the company's value to fall and investors will withdraw its shares, so it is very important for the banking world to pay attention to corporate governance.

The term corporate governance or good coporate governance (GCG) itself was first expressed by the Cadburry committee which stated that GCG is the principle that directs and controls the company to achieve a balance between the strength and authority of the company in carrying out and give accountability to the shareholders in particular, and stakeholders in general. It is intended that there is an arrangement of authority of directors, commissioners, and audit committee. Corporate governance is a proposed concept for improving company performance through supervision or monitoring of management performance and ensuring accountability of management to stakeholders by basing the regulatory framework (Nasution \& Setiawan, 2007). The implementation of GCG principles is expected to increase the company's value achieved if the company is able to operate by meeting the targeted profit. The benefits of the implementation of GCG one of them is to increase the productivity and efficiency of the company which of course a big impact on corporate profits that impact on investor confidence (Tumewu \& Aleander, 2014).

According to KNKG the theoretical implementation of GCG will be effective if following the basic principles set by KNKG that is transparency, accountability, responsibility, independence and obligation and equality. With reference to the five principles, then the practical key to the success of GCG is determined by the organs of companies involved in the management of the company. The organs of the company are the determining factor that ensures that all stakeholders' interests can be guaranteed and cared for, so that no stakeholders are harmed or neglected by their interests (Puteri, 2012).

With regard to corporate organs, the composition of board members is an issue that also relates to corporate governance. 
The existence of distribution or diversity on board members is believed to affect the value of the company, both in the short term and long term. Council districts are often called for increased council effectiveness and monitoring, and will improve company performance (Carter, 2003). Based on the findings of the behavioral research group, the group that varies, when managed properly will result in more innovative business decisions than homogeneous groups. The distribution of the council is expected to have a positive impact. The greater the dispersion within council members can lead to more conflicts, but the spread can provide an alternative solution to an increasingly diverse problem than homogeneous council members.

There are several previous studies on the impact of GCG on financial performance such as Istighfarin \& Wirawati research (2015) which shows that institutional ownership and CGPI have a significant positive effect on profitabilias, while independent board and audit committee variables have no significant effect on profitability. Ali and Saad's research (2015) shows that board size, board independence, ceo duality, and audit committees have a significant effect on financial performance. Sunarwan's research (2014) shows that the number of boards of directors, commissioners, audit committees has no significant effect on financial performance, while board meetings and Sharia council meetings have a significant effect on financial performance.

Tertius and Christiawan's research (2015) shows that boards of commissioners and managerial ownership have no significant effect on profitability, while independent commissioners and firm size have an effect on profitability. Carter's study (2003) shows that there is a significant positive influence between female and minority fractions in the board with firm values. Research Sari et al (2007) shows that the existence of female directors, the existence of ethnic Chinese, the proportion of outsider directors, age, and educational background of board members have no significant effect on Tobin's Q. Based on the results of previous studies that produce different conclusions that the researchers are interested to validate the results of research on the influence of GCG mechanism, board diversity to the financial performance of banking companies.

This study entitled the influence of good corporate governance mechanism on the company's financial performance at a banking company listed on the Indonesia Stock Exchange (IDX), which is the development of Abdullah and Rohmie's research in 2017 regarding corporate governance mechanisms on financial performance at Banks in Nigeria. In the study showed that the variable board size and audit comitee have no significant negative effect on ROA. The development in this research is done by adding two independent variables, the education background of the board of directors and the education background of the board of commissioner of Amin \& Sunarjanto research in 2016 concerning the influence of the board of commissioners and the board of directors on the performance of the company. The study shows that educational background has a significant effect on ROA, but it has no significant effect on PBV.

This study takes a sample of the banking sector because as mentioned above, that the banking scandal mostly involves insiders. In addition, corporate governance in the banking world has its own specificity as evidenced by many GCG guidelines specifically for banking. In determining the GCG characteristics in this study added the educational background variables of the board of directors and the board of commissioners.

\section{Problem Formulation}

Based on the background that has been described above then the formulation of the problem to be studied is first, how the influence of the size of the board of directors on the financial performance of the company. Second, how does the board of 
commissioner's size affect the company's financial performance. Thirdly, how does the audit committee measure the firm's financial performance. Fourth, how the educational background of the board of directors and board of commissioners on the financial performance of the company.

\section{LITERATUR REVIEW}

\section{Agency Theory}

Agency theory is the basic theory to understand the concept of corporate governance. Agency theory explains that agency relationships arise when one or more people (principal) hire another person (agent) to provide a service and then delegate authority to the agent to make the best decision for the principal. If the agent does not act in the interests of the principal, then there will be agency conflicts that trigger the emergence of agency costs (Husnan \& Pudjiastuti, 2012). Jensen and Mecking (1976) define agency costs in three types, namely monitoring costs, expenditures used to monitor agency activities, bonding costs, to ensure that agents will not act that can harm the principal, residual loss, is the value of money equivalent to the reduction of prosperity experienced by the principal as a result of different interests.

\section{Corporate Governance}

Corporate governance is a concept that the definition can vary. The term corporate governance was first introduced by the Cadburry Comite in 1922 in its report called the cadburry report. Corporate governance is a set of rules governing relationships between shareholders, managers of companies, creditor parties, governments, employees, and other internal and external stakeholders related to their rights and obligations, or in other words a system that directs and controls company (FCGI, 2001).

\section{Corporate Governance Mechanism}

\section{Board of Commissioners}

According to the 2004 special banking KNKCG legally the board of commissioners is in charge of supervising and advising the board of directors. Members of the board of commissioners are elected and dismissed by the GMS through a transparent process. The board of commissioners is known by the President Commissioner responsible for the effective and efficient implementation of the board of commissioners and the maintenance of communication effectiveness among the board of commissioners with directors, external auditors and the Supervisory Authority of the Bank.

\section{Board of Directors}

In accordance with applicable laws and regulations, the board of directors is fully responsible for the management of the company and represents the company both inside and outside the company. The Board of Directors shall have the right and obligation to implement the provisions contained in the Bank's articles of association, to implement vision, mission, strategy, business goals and long-term and short-term plans, to implement sound banking principles, but not limited to risk management and internal control systems.

\section{Audit Committee}

The Audit Committee is an important organ in order to ensure the implementation of the principle of Checks and Balances. The Bank shall establish an Internal Audit Working Unit responsible for the conduct of internal audits. As an internal auditor, the organizational unit must be able to perform its duties independently and be able to advise improvements to the unit being audited (KNKCG, 2004).

\section{Board Members Diversity}

Board diversity is often defined as the personal division among interdependent members of the work unit (Clarke \& 
Branson, 2012). Carter et al (2007) suggests that today many companies recognize that employee diversity and top management provide some benefits for companies such as enlarging creativity, because employee diversity can stimulate alternative considerations that are less clear, improve decision-making, because homogeneous groups tend to in the direction of groupthink, enlarge the flexibility of the system, because diversity at different levels results in more openness to new ideas in general and greater tolerance of doing things in different ways, the existence of management decisions with unique perspectives, creativity and other innovative income, improving management oversight, providing access to more constitutions and other external environmental sources, providing legitimacy for companies with both internal and external constitutions.

\section{Corporate Financial Performance}

This study uses the company's performance measurement ROA. ROA is the ratio used to measure the company's management capability in obtaining profit by utilizing the total total assets owned (Attar et al, 2014). ROA measures how effectively a company can convert revenue from return on investment into assets. The higher the company's ROA the better the company's performance.

\section{Hypothesis}

\section{The size of the Board of Directors on the Company's Financial Performance}

The number of boards of directors has an influence on whether or not decisionmaking is fast due to the need for coordination in order to reach agreement. The existence of the separation of roles with the board of commissioners, then the board of directors becomes more freely to manage all the resources that exist within the company. Putu Ayu's research (2012) shows that the number of board of directors influences the company's financial performance, whereas according to research of Jensen (1993) shows that the large number of board of directors will give negative effect to the company's financial performance. Based on the description above then the hypothesis to be tested as follows:

$\mathrm{H}_{1}$ : The size of the board of directors affects financial performance.

\section{The size of the Board of Commissioners on the Company's Financial Performance}

The board of commissioners is responsible for overseeing the performance of the company and providing input to the board of directors (FCGI, 2001). Supervision is done so that the agency does not take an opportunistic action for himself, thus it is expected that management can act in accordance with the interests of the owner is to increase the return as measured by ROA. Jensen's research (1993) shows the result that the number of board of commissioners has a negative impact on the company's financial performance, while in the research Jacking and Johl (2009) shows that the size of the board of commissioner has a positive effect on the financial performance of the company. Research by Ibrahim \& Samad (2011) also shows that board size affects the company's financial performance. Based on the above description then the hypothesis to be tested as follows:

$\mathrm{H}_{2}$ : the size of the board of commissioners affects the financial performance.

\section{The size of the Audit Committee on the Company's Financial Performance}

The task of the audit committee is to strengthen the oversight function of the board of commissioners on the financial reporting, risk management, audit and GCG implementation processes within the company. The existence of this audit committee will make the performance of the company more controlled and more secure level of honesty. Sulestyo and Ghozali (2012) stated that audit committee has a significant positive effect on company profitability, but in research conducted by 
Herdianto (2013) revealed different result that audit committee has no effect on company financial performance. Based on the above description then the hypothesis to be tested as follows:

$\mathrm{H}_{3}$ : Audit committee size has an effect on financial performance.

\section{Background of Board Member Education on Corporate Financial Performance}

Although it is not a must for someone who will enter the business world for business education, it would be better if board members have business and economic knowledge. Given the existing business and economic knowledge, at least board members have better ability to manage business and take business decisions than have no business and economic knowledge. Ultimately this will affect the company's performance (Kusumastuti, 2007). Research Kusumatuti et al (2007) shows that educational background negatively affect the value of the company, but in research Raharjanti (2010) indicates that the educational background does not affect the value of the company. Based on the above description then the hypothesis to be tested as follows:

$\mathrm{H}_{4}$ : The percentage of the board of directors with an economic education background (business, management, finance) affects the company's financial performance.

$\mathrm{H}_{5}$ : Percentage of board of commissioners with economic education background (business, management, finance) has an effect on company's financial performance.
These hypotheses if described in a model will be:

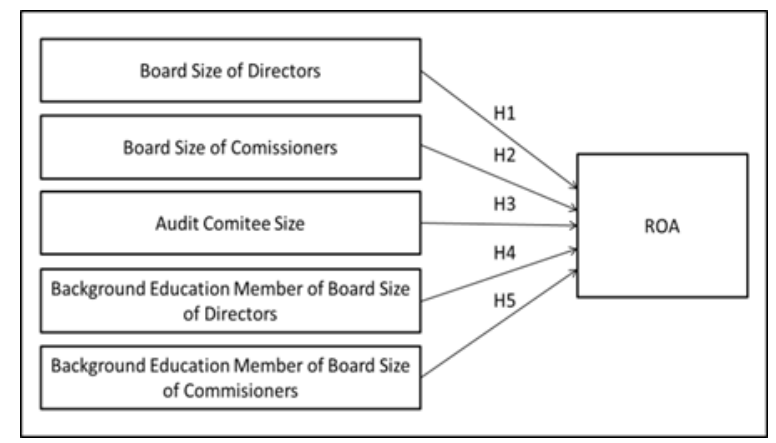

Source: Processed by Author

\section{RESEARCH METHODS}

\section{Research Methods}

This research method using quantitative approach. The author uses quantitative research methods because this study aims to measure the relationship of independent variables such as the size of the board of directors, the size of the board of commissioners, the size of the audit committee, the education background of the board of directors, the education background of the board of commissioners with the dependent variable in the form of ROA. The data used in the form of secondary data obtained from the financial statements of banking companies listed on the Indonesia Stock Exchange (IDX) period 2012-2016 which has met the criteria through the official website www.idx.co.id.

\section{Dependent Variables}

The dependent variable in this study is the company's financial performance proxies with return on assets (ROA).

$$
R O A=\frac{\text { net profit before tax }}{\text { total assets }} \times 100 \%
$$

\section{Independent Variables \\ Board size of directors}

In accordance with applicable laws and regulations, the board of directors is fully responsible for the management of the 
company and represents the company either inside or outside the company. According to OJK, the bank must have a minimum number of members of the board of directors of 3 people.

Board size of directors= number of members of the board of directors within the company

\section{Board size}

Board of commissioners is part of the company that serves to supervise the performance of the board of directors. According to OJK the minimum member of the board of commissioners of the banking system consists of three people and at most as many members of the board of directors.

Board size of commisioners= number of the board of commisioners within the company

\section{Audit Committee Size}

The audit committee is a corporate organ appointed by the board of commissioners to assist the oversight function undertaken by the board of commissioners and also to assist the auditor in maintaining the independence of management. According to OJK audit committee as referred to in Article 34 paragraph 1 letter a consists of at least 3 people.

Audit Comitee Size= number of members of the audit comitee within the company

\section{Background Education Member of Board of Directors and Commissioners}

Latar belakang pendidikan formal anggota dewan The formal education background of members of the board of directors and commissioners is a cognitive characteristic that may affect the board's ability to make business decisions and manage business (Kusumastuti et al., 2007).

\footnotetext{
Background education $=\frac{\text { board member with economic education background }}{\text { number of board members }} \times 100 \%$
}

Table 1 Sample Characteristics

\begin{tabular}{lcccccc}
\hline \multicolumn{1}{c}{ Kriteria } & 2012 & 2013 & 2014 & 2015 & 2016 & Jumlah \\
\hline Publish financial statements & 31 & 36 & 39 & 41 & 42 & 189 \\
In foreign currency & 0 & 0 & 0 & 0 & 0 & 0 \\
Does not contain information on the size of the & & 3 & 2 & 1 & 3 & 9 \\
board of directors, the size of the board of & & & & & \\
commissioners, the size of the audit comitee, the \\
education of the members of the board of \\
directors, the education of the members of the
\end{tabular}

board of commissioners

\begin{tabular}{lllllll}
\hline Number of samples & 31 & 33 & 37 & 40 & 39 & 180 \\
\hline
\end{tabular}

Sumber: Diolah Sendiri

\section{Data collection technique}

Data collection techniques used in this study is archive data collection techniques or documentation on the database. To obtain secondary data in the form of company financial statements can be through the website www.idx.co.id for financial statement data. The data used in this research is cross section data.

\section{Data Processing Technique}

Data collection techniques used in this study is archive data collection techniques or documentation on the database. To obtain secondary data in the form of company financial statements can be through the website www.idx.co.id for financial statement data. The data used in this research is cross section data.

\section{Data Analysis Technique}

Testing the research hypothesis by using simple linear regression analysis in SPSS 22 program with the following sequence:

\section{Classic assumption Test}

The classical assumption test is used to test the accuracy of the model. Classic assumption test used is normality test and heterokedastisity test.

\section{Hypothesis Testing}

Hypothesis testing in this study using statistical test $t$. If the probability significance value $<0.05$ means there is a significant influence between independent 
variables partially with the dependent variable (Ghozali, 2012). The model of regression equation in this research are:

$$
\begin{aligned}
& Y=\alpha+\beta_{1} X_{1}+\varepsilon \ldots \\
& Y=\alpha+\beta_{2} X_{2}+\varepsilon \ldots \\
& Y=\alpha+\beta_{3} X_{3}+\varepsilon \ldots \\
& Y=\alpha+\beta_{4} X_{4}+\varepsilon \ldots \\
& Y=\alpha+\beta_{5} X_{5}+\varepsilon \ldots
\end{aligned}
$$

Explanation:

$\mathrm{Y}=$ Company's financial performance

$\alpha=$ Constants

$\beta_{1-} \beta_{4}=$ Regression coefficient of each independent variable dependen

$\mathrm{X}_{1} \quad=$ Size of the board of directors

$\mathrm{X}_{2}=$ The size of the board of commissioners

$\mathrm{X}_{3} \quad=$ Audit committee size

$\mathrm{X}_{4} \quad$ = Educational background of the board of directors

$\mathrm{X}_{5}=$ Educational background of the board of directors

$\mathrm{X}_{5}=$ Educational background of the board of commissioners

\section{RESULTS AND DISCUSSION}

\section{Statistik Deskriptif}

Table 2 Results Descriptive Statistics

\begin{tabular}{lccccc}
\hline \multicolumn{1}{c}{ Variable } & $\mathrm{N}$ & Min & Max & Mean & Std. Deviation \\
\hline Board Size of Directors & 180 & 3.00 & 12.00 & 6.5389 & 2.57266 \\
Board Size of Commisioners & 180 & 1.00 & 7.00 & 2.6000 & 1.31430 \\
Audit Comitee Size & 180 & 2.00 & 9.00 & 3.6222 & 1.07358 \\
Board of Director's Education & 180 & 0.20 & 1.00 & 0.7836 & 0.17231 \\
Board of Commissioner's Education & 180 & 0.25 & 1.00 & 0.7237 & 0.25776 \\
Return On Asset & 180 & $-0,1173$ & 0.5193 & 0.164330 & 0.1275817 \\
\hline Description : This table is a table of descrintive statistics The dependent variable POA is derved from the income statement The
\end{tabular}

Description : This table is a table of descriptive statistics. The dependent variable ROA is derved from the income statement. The
independent variables are board of director size, board of commisioners size, audit comitee size, board of director's education,

board of commissioner's education are obtained on profile information of the company's board in the annual report of banking

company.

Source: Data processed with SPSS 20

Based on table 2 above, it can be seen that the amount of data used in this study is 180 sample data, this study examines the dependent variable that is the company's financial performance measured by ROA and independent variables that is the size of the board of directors, board size, size of the audit committee, board member education, and board member education.
Based on the descriptive statistics of Table 2 it is known that the first component of the board size has a minimum value of 3 , meaning that the number of members of the board of directors in the banking company is a minimum of 3 persons, this means that all banks listed on the BEI have complied with the provisions of OJK stating that the total number of members of the board of directors shall be at least 3 persons. The maximum number of boards of existing board of directors in the banking company amounted to 12 , meaning the number of members of the board of directors in the banking company a maximum of 12 people. The average value of the board size of 6.5389 is rounded to 7 people. Standard deviation of 2.57266 .

The second component of the size of the board of commissioners has a minimum value of 1 , meaning the number of members of the board of commissioners existing in banking companies a minimum of 1 person. This shows that there are still some banks listing on the IDX has not met the provisions of OJK that is that the minimum number of board of commissioners is 3 people. Maximum size of the existing board of commissioners of banking companies that amounted to 7 . The average value of the size of the board of commissioners that amounted to 2.6000 rounded to 3 people. Standard deviation of 1.31430 .

The third component of the audit committee's size has a minimum value of 2 , meaning that the number of members of the audit committee available to a banking company is a minimum of 2 persons. This shows that the number of members of the audit committee has not met the requirements of OJK that must be at least 3 people. The maximum number of existing audit committees of banking companies is 9 . The average value of board size of 3.6222 is rounded to 4 . Standard deviation of 1.07358 .

The fourth component of the education of members of the board of directors has a minimum value of 0.20 means the minimum number of members of the board of directors with an economic 
education background of 0.20 or $20 \%$ of the total number of members of the board of directors, and the maximum number of members of the board of directors is 1 , The fourth component of the education of members of the board of directors has a minimum value of 0.20 means the minimum number of members of the board of directors with an economic education background of 0.20 or $20 \%$ of the total number of members of the board of directors, and the maximum number of members of the board of directors is 1,00 means the maximum number of members of the board of directors with an economic education background of 1.00 or $100 \%$ of the total number of members of the board of directors. The average value of education of members of the board of directors with economic and business education background is 0.7836. Standard deviation of 0.17231 .

The fifth component of the education of members of the board of commissioners has a minimum value of 0.25 , meaning that the minimum number of members of the board of commissioners with economic and business education background is 0.25 or $25 \%$ of the total number of members of the board of commissioners, and the maximum number of members of the board of commissioners economic and business education background of 1.00 means the maximum number of members of the board of commissioners with an economic education background is 1.00 or $100 \%$ of the total number of members of the board of commissioners. The average value of members of the board of commissioners with an economic and business education background is 0.7237 . Standard deviation of 0.25776 .

The sixth component of return on assets has a minimum value of -0.1173 and the maximum amount of return on assets is 0.5193 . The average value of return on assets is 0.164330 . Standard deviation of 0.1275817 .

\section{Hypothesis Testing}

Based on the results of regression testing with 418 manufacturing companies listed on the Indonesia Stock Exchange (BEI), the period used in 2011-2016 using SPSS 20 program then the test results can be summarized as follows:

\section{Hypothesis 1}

The first hypothesis proposed in this study states that the size of the board of directors affect the return on assets of banks. This hypothesis can be supported if the significance value is $<0.05$ and can not be supported if otherwise. The results of the analysis can be seen in table 3 as follows:

Table 3. Result of Size Analysis Board of Directors Affects Financial Performance

\begin{tabular}{llll}
\hline Variable & Coefficient & t-calculate & Sig \\
\hline Constanta & 0,018 & 0,756 & 0,450 \\
Board size of Directors & 0,022 & 6,769 & 0,000 \\
R-Square & 0,452 & & \\
Adjusted R-Square & 0,205 & & \\
\hline
\end{tabular}

Source: Data processed with SPSS 20

Based on the above table it can be seen that the significance level of 0.000 is smaller than $\mathrm{a}=5 \%$, so the first hypothesis can be supported. The adjusted R-square value of 0.205 indicates that the size of the board of directors is able to explain the ROA of $20.5 \%$, while the rest of $79.5 \%$ is explained by other causes outside the model.

These results have been tested with classical assumptions. The normality test using the Kolmogorov-smirnov test of 0.699 indicates that the data is normally distributed. The results of testing the first hypothesis are free from the classical assumption. Glejser test value 0.355 indicates that the regression performed there are no symptoms of heteroskedastisitas because the value is above the standard 0.05 so it is still within the limits of tolerance.

\section{Hypothesis 2}

The second hypothesis proposed in this study states that the size of the board of commissioners affect the return on assets of 
banks. This hypothesis can be supported if the significance value is $<0.05$ and can not be supported if otherwise. The results of the analysis can be seen in table 4 as follows:

Table 4 Results Analysis of the size of the Board of Commissioners Affects Financial Performance

\begin{tabular}{llll}
\hline Variable & Coefficient & t-calculate & Sig \\
\hline Constanta & 0,080 & 4,006 & 0,000 \\
Board size of Commisioners & 0,032 & 4,730 & 0,000 \\
R-Square & 0,334 & & \\
Adjusted R-Square & 0,112 & & \\
\hline
\end{tabular}

Source: Data processed with SPSS 20

Based on the above table it can be seen that the significance level of 0.000 is smaller than $\mathrm{a}=5 \%$, so the second hypothesis can be supported. The adjusted $\mathrm{R}$-square value of 0.112 shows that the size of the board of commissioners is able to explain the ROA of $11.2 \%$, while the remaining $88.8 \%$ is explained by other causes outside the model.

These results have been tested with classical assumptions. The normality test using Kolmogorov-smirnov test of 0.334 indicates that the data is normally distributed. The results of testing the first hypothesis are free from the classical assumption. Glejser test value 0.664 indicates that the regression performed there are no symptoms of heteroskedastisitas because the value is above the standard 0.05 so it is still within the limits of tolerance.

\section{Hypothesis 3}

The third hypothesis proposed in this study states that the size of the audit committee board influences the return on asset banking. This hypothesis can be supported if the significance value is $<0.05$ and can not be supported if otherwise. The results of the analysis can be seen in table 5 as follows:

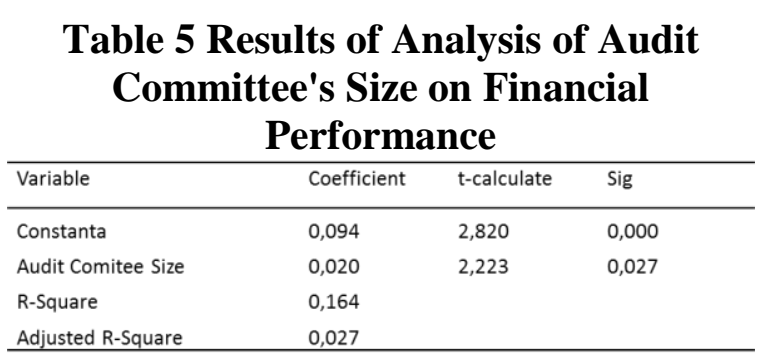

Source: Data processed with SPSS 20

Based on the above table it can be seen that the significance level of 0.027 is smaller than $\mathrm{a}=5 \%$, so the third hypothesis can be supported. The adjusted R-square value of 0.027 indicates that the audit committee's size is able to explain the ROA of $2.7 \%$, while the rest of $97.3 \%$ is explained by other causes outside the model. These results have been tested with classical assumptions. The normality test using the Kolmogorov-smirnov test of 0.586 indicates that the data is normally distributed. The results of testing the first hypothesis are free from the classical assumption. Glejser test score of 0.737 indicates that the regression performed there are no symptoms of heteroskedastisitas because the value is above the standard 0.05 so it is still within the limits of tolerance.

\section{Hypothesis 4}

The fourth hypothesis proposed in this study states that the size of the board of directors affect the return on asset banking. This hypothesis can be supported if the significance value is $<0.05$ and can not be supported if otherwise. The results of the analysis can be seen in table 6 as follows:

\begin{tabular}{|c|c|c|c|}
\hline & Coefficient & t-calculate & Sig \\
\hline Constanta & 0,145 & 3,266 & 0,001 \\
\hline Member of Director's Education & 0,024 & $-0,438$ & 0,662 \\
\hline R-square & 0,033 & & \\
\hline Adjusted $R$ & 0,001 & & \\
\hline
\end{tabular}

Source: Data processed with SPSS 20 
Based on the above table shows that the level of significance of 0.662 is greater than $\mathrm{a}=5 \%$, so the fourth hypothesis is not supported. The adjusted R-square value of 0.001 indicates that the audit committee size is able to explain the ROA of $0.1 \%$, while the rest of $99.9 \%$ is explained by other causes outside the model.

These results have been tested with classical assumptions. The normality test using the Kolmogorov-smirnov test of 0.515 indicates that the data is normally distributed. The results of testing the first hypothesis are free from the classical assumption. Glejser test value 0.218 indicates that the regression performed there are no symptoms of heteroskedastisitas because the value is above the standard 0.05 so it is still within the limits of tolerance.

\section{Hypothesis 5}

The fifth hypothesis proposed in this study states that the board of commissioner's education affect the return on asset banking. This hypothesis can be supported if the significance value is $<0.05$ and can not be supported if otherwise. The results of the analysis can be seen in table 7 as follows:

\begin{tabular}{|c|c|c|c|}
\hline able & coefficient & $\begin{array}{l}\mathrm{t} \text {-calculate } \\
\text { nate }\end{array}$ & Sig \\
\hline tanta & 0,193 & 6,783 & 0,000 \\
\hline nber of Commisioner's Education & $-0,039$ & $-1,059$ & 0,291 \\
\hline jquare & $\begin{array}{l}0,079 \\
0.006\end{array}$ & & \\
\hline
\end{tabular}

Source: Data processed with SPSS 20

Based on the above table shows that the level of significance of 0.291 is greater than $\mathrm{a}=5 \%$, so the fifth hypothesis is not supported. The adjusted R-square value of 0.006 shows that the board of commissioners' education is able to explain the ROA of $0.6 \%$, while the rest of $97.1 \%$ is explained by other causes outside the model. These results have been tested with classical assumptions. Normality test using
Kolmogorov-smirnov test of 0.346 indicates that the data is normally distributed. The results of testing the first hypothesis are free from the classical assumption. Glejser test score of 0.338 indicates that the regression performed there is no symptoms of heteroskedastisitas because the value is above the standard 0.05 so it is still within the limits of tolerance.

\section{Data Analysis}

\section{The Size of The Board of Directors Affects Financial Performance}

Based on the results of statistical tests described in Table 4:10 shows that the size of the board of directors have a significant effect on the return on assets of banks. This result is in accordance with Ong et al (2015) study which states that the size of the board of directors has a significant effect on ROA. Similarly, research by Panky \& Rahardja (2014) which states that the size of the board of directors has a significant effect on ROA.

Many or at least the number of members of the board of directors will affect the financial performance of the company. The large number of boards allows for quality improvement from decisions taken by companies because decision-making will not focus on one party only. The right and effective decision will improve the company's financial performance. The growing number of directors in quantitative terms will help the company benefit, especially when viewed from resource dependence (Wardhani, 2006). In addition, the need for an increasingly effective external relationship will also have implications for the growing need for large directors, but the large number of board members can lead to lengthy decisionmaking because of difficulties in coordination. A small number of board members may not necessarily have a negative impact on the company, as fewer members of the board will ease and accelerate decision making in order to make time efficient. 
The Size of The Board of Commissioners Affects Financial Performance

Based on the results of statistical tests that have been described in Table 4:10 shows that the size of the board of commissioners berpengarh significant to return on assets. This result is in accordance with the research of Sherly \& Imam (2015) which states that the size of the board of commissioners has a significant influence on the financial performance of the company. Similarly, Adestian research (2015) which states that the size of the board of commissioner influential effect on ROA.

The number of boards of commissioners that many or at least amounted to 3 people will make it easier for members of the board of commissioners to run and divide the task. Specifically, the proportion of the larger board of commissioners is considered capable of producing quality supervision processes, so that all of the company's policies and policies can be run in accordance with the stipulated requirements. The amount of the board of commissioners that is large or comparable to the number of boards of directors will be very useful if the board of directors and board of commissioners have differences of opinion. If the number of boards is small then there is a possibility that the board of commissioners has psychological pressure. However, if a member of the board of commissioners does not instill GCG principles into himself then the large number of boards of commissioners will cause a problem because the board of commissioners will be easily tempted and not concerned with the interests of the company (Kusuma, 2008).

\section{The Size of The Audit Committee Affects Financial Performance}

Based on the results of statistical tests that have been described in table 4:10 shows that audit committee size significantly influence the financial performance of the company. This result is in accordance with research Mahardika (2015) which states that the size of the audit committee affects the financial performance of the company. Similarly, the research of Princess (2015) which states that audit committee size has no effect on ROA..

High or low number of audit committees in a company affect the profitability of the company. This shows that the existence of an effective audit committee can improve the financial performance of the company because it can suppress the occurrence of accounting irregularities that are often committed by management parties that harm the shareholders and the company itself (Mahardika, 2015). The number of audit committees in banking companies listed on the IDX during the study period has shown the establishment of an effective audit committee because all banking companies have met the minimum requirements of the audit committee of OJK that is at least 3 persons. According to the Guidelines for the Establishment of an Effective Audit Committee drawn up by the National Committee of Good Corporate Governance in 2002 stated that one of the functions of the audit committee is to improve the quality of financial statements by overseeing the financial statements on behalf of the board of commissioners, thus minimizing the extent of fraud committed by the parties management that ultimately can affect the financial performance of the company.

\section{Percentage of the Board of Directors Background Economic Education (Business, Management, Finance) Affects the Company's Financial Performance.}

Based on the results of statistical tests described in Table 4:10 shows that the background of the board of directors' education has no significant effect on the financial performance of banking companies. This result is in accordance with research Kusumastuti (2007) which states that the education background of the board of directors has no significant effect on the financial performance of the company. Similarly, Sri \& Samiaji (2013) study stated 
that the education background of the directors has no effect on ROA.

This suggests that the board's educational background is not an influence in the financial performance of the company, although in the field of education members of the board of directors already have provision for economic education (management, finance and business) but if it is not accompanied by other skills such as leadership good experience, qualified work experience then it will not give a significant effect on the financial performance of the company. In addition, for the board of directors more needed educational background or discipline appropriate field or sector of the company concerned to take important decisions (Kusumastuti, 2007).

\section{Percentage of the Board of Commissioners Background on Economic Education (Business, Management, Finance) Affects the Company's Financial Performance}

Based on the results of statistical tests described in table 4.10 shows that the background of board of commissioners education does not significantly affect the financial performance of banks. This study is in accordance with research Kusumastuti (2007) which states that the board of commissioners who have the background of economic education (business, management, finance) have a significant influence on ROA.

This indicates that the board of commissioner's education background is not an influence in the financial performance of the company, as is the board of directors, although in the field of education the member of the board of commissioners has the provision of economic education (management, finance and business) but if it is not accompanied with softskill others such as good leadership, qualified work experience then it will not give a significant effect on the financial performance of the company (Kusumastuti, 2007). This is also due to the unbalanced comparison of the number of boards of commissioners to the number of boards of directors, so that although the board of commissioners already have a good educational background in the economic field, this becomes no effect due to the number of board of commissioners very little so that the supervisory function becomes less maximal (Kusuma, 2008).

\section{CONCLUSIONS}

The purpose of this research is to know the effect of board size, board of commissioner size, audit committee size, board member education and board member of commissioner toward financial performance of banking in Indonesia which listed on BEI in period 2012-2016. The author has done the sampling and there are 42 banks who become samples in the study with the amount of research data as much as 180 research data. Research data is secondary data in the form of financial statements and has free classical assumption test. Based on the results of the analysis can be taken some conclusions that the size of the board of directors have a significant influence on corporate financial performance, board size has a significant influence on corporate financial performance, (economic, business, management, finance) have no significant influence on the financial performance of the company.

\section{Limitations and Suggestions}

The authors found several limitations in this study. Some of the limitations are the sample in this study is only limited to companies in the field of banking listed on the BEI, the sample data only comes from a period of five years, ie year 2012-2016, the dependent variable that the author uses only return on assets.

Based on the limitations of the problems that have been described above, there are some suggestions for further research that further research is expected to increase the number of samples, not only limited to banking, but add samples to the entire financial sector in order to research 
become wider, the research is better, the size of different companies causes the data to be unbalanced, so that the next researcher can add control variables in the form of company size, subsequent research on the variable is expected to use other dependent financial ratios such as EVA, ROE, and NPM.

\section{BIBLIOGRAPHY}

Abdullah, \& Rohami.(2017). Corpoarate Governance as a Mechanism Financial Performance of Banks in Nigeria. Journal of Finance, Accounting,Managmenent.Vol.08.No $.1,1-19$.

Adestian, Y. (2015). Pengaruh Dewan Komisaris, Dewan Direksi, Dewan Komisaris Independen, Komite Audit dan Ukuran Perusahaan Perbankan yang Listing Di BEI Tahun 2012-2014.

Amin, \& Sunarjanto.(2016). Pengaruh Diversitas Dewan Komisaris dan Dewan Direksi Terhadap Kinerja Perusahaan.

Attar, Ishlahuddin, \& Shabri.(2014). Pengaruh Penerapan Manajemen Risiko terhadap Kinerja Keuangan Perbankan yang Terdaftar di Bursa Efek Indonesia. Jurnal Akuntansi.

Carter.(2003). Corporate Governance, Board Diversity, and Firm Value. The Finnacial Review, 33-53.

FCGI. (2001). Corporate Governance Self Assesment Checklist. Jakarta: Citra Graha.

Ghozali.(2012). In Aplikasi Analiis Multivariate dengan Prograam SPSS 20. Semarang: Badan Penerbit Universitas Diponegoro.

Herdianto, F. (2013). Pengaruh Good Corporate Governance terhadap
Tingkat Profitabilitas Bank Umum Syariah di Indonesia.

Ibrahim, \& Samad. (2011). Corporate Governance Mechanism and Performance of Public Listed Family Ownership in Malaysia. International Journal of Economics and Finance, 13-27.

Istighfarin, D., \& Wirawati, N. G. (2015). EJournal Akuntansi Universitas Udayana Vol.13.No.2.

Jacking, B., \& Johl, S. (2009). Board Structure and Firm's Performance : Evidence from India's Top Companies. Corporate Governance : an International Review.

Jensen, \& Mecking. (1976). Theory of The Firm : Managerial Behavior, Agncy Costs and Ownership Structurre. Journal of Financial Economics, 305-360.

Jensen, M. (1993). The Modern Industrial Revolution, Eit and the Failure of Internal Control System. Journal of Finance, 831-880.

Kasmir.(2005). Bank \& Lembaga Keuangan Lainnya. Jakarta: Raja Grafindo Persada.

Kasmir.(2008). Analisis Laporan Keuangan. Jakarta: Rajawali Pers.

KNKCG. (2004). Pedoman Good Corporate Governance Perbankan Indonesia. Komite Nasional Kebijakan Corporate Governance.

KNKG. (2012). Prinsip Dasar Pedoman Corporate Governance Perbankan Indonesia. Komite Nasional Kebijakan Governance.

Kusumastuti, S., Supatmi, \& Sastra, P. (2007). Pengaruh Board Diversity terhadap Nilai Perusahaan dalam Perspektif Corporate Governance. 
Mahardika, M.(2015). Pengaruh Direksi, Komite Audit, Kepemilikan Institusional, dan Penerapan Prinsip Good Corporate Governance Terhadap Kinerja Keuangan Perusahaan.

Mandasari, P. Y., Kamaliah, \& Hanif, R. A. (2013). The Influences of Corporate Social Responsibility to Firm Value with Profitability and Leverage as a Moderating Variable. Jurnal Ekonomi, Volume 21, Nomor 4.

Nasution, M., \& Setiawan, D.(2007). Pengaruh Corporate Governance terhadap Manajemen Laba di Industri Perbankan di Indonesia. Simposium Nasional Akuntansi X.

OJK.(2016). Penerapan Tata Kelola Bagi Bank Umum. Peraturan Otoritas Jasa Keuangan.

Ong, Heng, Ahmad, \& Muhammad. (2015). Relation between Corporate Governance Attributes and Financial Performance in Oil and Gas Industries. Institutions and Economics.Vol7., 56-84.

Orij, R. (2007). Corporate Social Disclosures and Accounting Theories. Lisbon: 30th Annual Congress of the European Accounting.

Puteri, A. (2012). Karakteristik Good Corporate Governance dan Kinerja Perusahaan Manufaktur.

Rahardja. (2014). Pengaruh Ukuran Dewan Direksi dan Dewan Komisaris serta Ukuran Perusahaan terhadap kinerja keuangan perusahaan.

Sulestyo, T. R., \& Ghozali, I. (2012). Pengaruh Pemegang Saham Institusi, Komisaris Independen dan Komite Audit terhadap tingkat profitabilitas perusahaan. Diponegoro Journalof Accounting.
Sunarwan, E.(2014). Pengaruh Good Corporate Governance (GCG) Terhadap Kinerja Keuangan Perbankan Syariah.

Wardhani.(2006). Mekanisme Corporate Governance dalam Perusahaan yang Mengalami Permasalahan Keuangan. Simposium Nasional Akuntansi IX, 23-26 Agustus. Universitas Padang. 